\title{
Comment on supposed holothurian body fossils from the middle Ordovician of Wales (Botting and Muir, Palaeontologia Electronica: 15.1.9A)
}

\author{
Andrew B. Smith, Mike Reich, and Samuel Zamora
}

\begin{abstract}
Light and SEM study of body fossils from the Middle Ordovician of Wales recently described as the oldest articulated holothurians by Botting and Muir (Palaeontologia Electronica Article number: 15.1.9A) finds no traits that allow them to be assigned to the Echinodermata.
\end{abstract}

Andrew B. Smith. Department of Earth Sciences, The Natural History Museum, Cromwell Road, London SW7 5BD, United Kingdom a.smith@nhm.ac.uk Mike Reich. Geowissenschaftliches Zentrum der Universität Göttingen, Museum, Sammlungen \& Geopark, Goldschmidtstr. 1-5, D37077 Göttingen, Germany mreich@gwdg.de

Samuel Zamora. Department of Earth Sciences, The Natural History Museum, Cromwell Road, London SW7 5BD, United Kingdom samuel@unizar.es

Keywords: Echinodermata; Porifera; Ordovician; taxonomic affinities

\section{COMMENT}

In a recent paper describing a middle Ordovician (Darriwilian) fauna from Wales, Botting and Muir (2012) assigned some vase-shaped fossils to the echinoderm class Holothuroidea, establishing a new genus and species, Oesolcucumaria eostre. While isolated skeletal elements of holothurians first appear at about this time (Reich, 1999, 2001) the fossil record of articulated holothurians is extremely sparse (Smith and Gallemí, 1991; Gilliland, 1993; Reich, 2010a, in press). So this discovery, if correct, has some importance: as the oldest articulated holothurians ever recorded, they could potentially provide critical evidence about the morphology of the earliest members of this class.
Oesolcucumaria was described as having a multiplated calcareous ring, skeletalized ambulacra, and cruciform dermal sclerites, though these last elements were illustrated only sketchily in the paper. The descriptions were based on light microscopic study of the original fossils preserved as moulds.

We studied the type material (NHM EE.8734, 8736-8739; Figure 1) using low-angle light microscopy but could find no traits that indicate this material has echinoderm affinities. We therefore cast two of the specimens and examined them under light and scanning electron microscopy in order to clarify aspects of its morphology. It is standard practice when studying echinoderms preserved as 

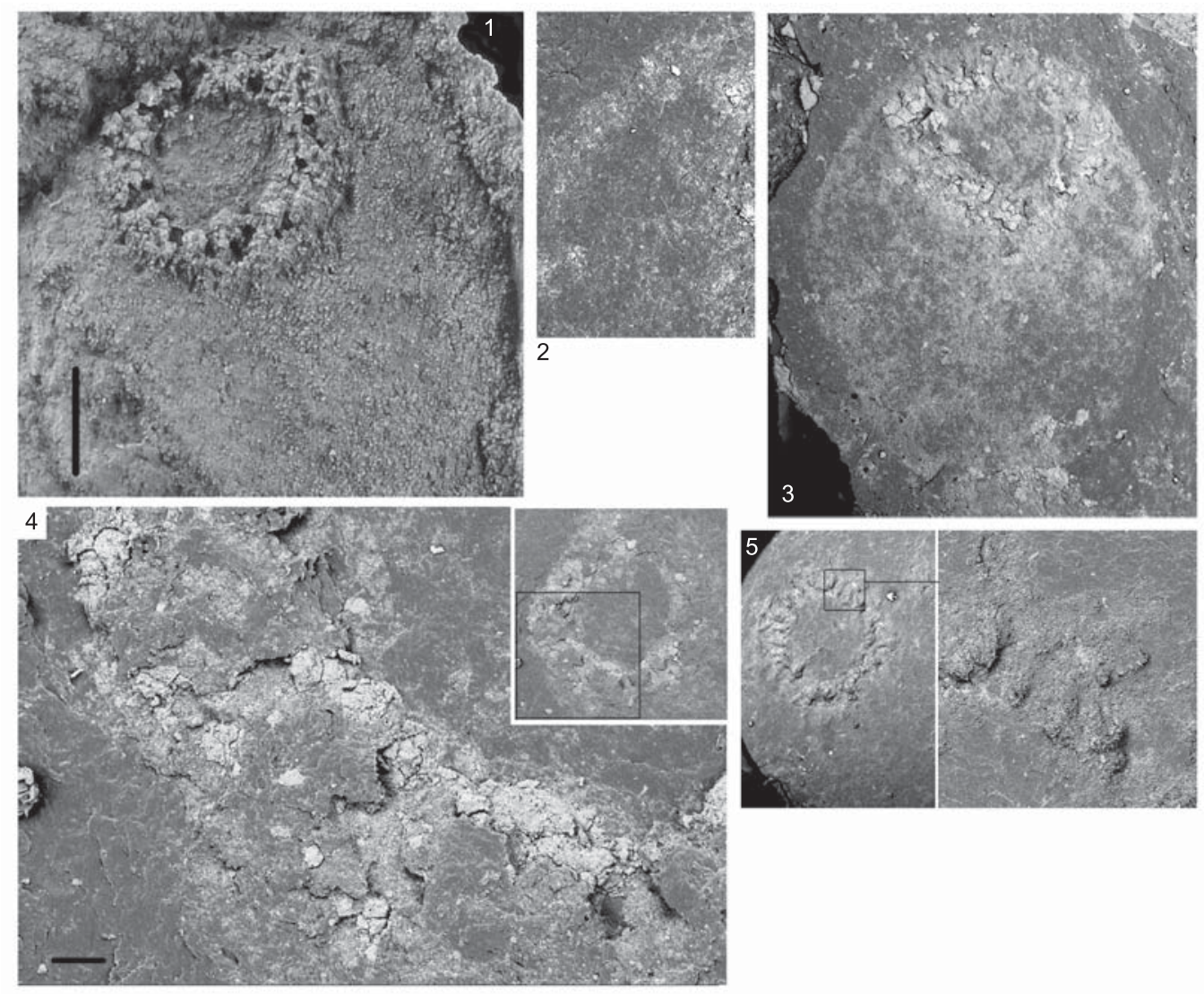

FIGURE 1. Oesolcucumaria eostre Botting and Muir, 2012, Darriwilian, middle Ordovician of Bach-y-Graig, Llandrindod, Wales. 1-4, NHM EE8734, latex cast of showing the structure of the oral ring. 2, SEM micrograph of the body wall showing fine acicular cruciform spicules. 3, SEM micrograph of body fossil. 4, SEM micrograph of part of the perioral ring (inset shows the complete ring); note the lack of regular structure. 5, NHM EE8739, SEM micrograph of the perioral ring; general view and detail showing granular microstructure. All specimens housed in the Natural History Museum, London. Scale bars: $1=1 \mathrm{~mm}$; $4=200 \mu \mathrm{m}$.

moulds to cast them in latex, as this is by far the best way to reveal details of plating. This is how other early Palaeozoic holothurian mouldic body fossils have been studied by previous authors (i.e., Haude, 1995b; Jell, 2011) and it is latex casts that are illustrated and described in those papers. While it is usual to remove iron oxides from specimens prior to latexing, as the iron oxide fill can obscure details, in this case the specimen was left untreated because of its delicate state of preservation. The latexes were examined under SEM because only at this level of resolution do the details of ossicle microstructure become evident.

A basic synapomorphy of all echinoderms is the presence of a calcitic skeleton with stereom microstructure. In holothurians the body wall skeleton is 'reduced' to small (and mostly) diagnostic platelets and ossicles (Seilacher, 1981; Gilliland, 1993) and only outer test scales, anal plates and calcareous ring elements retain the characteristic perforate microstructure. The Silurian holothurian Porosothyone (Jell, 2011), for example, has a body covered in flat ovoid platelets whose stereom microstructure is clearly apparent under the light microscope. No such elements were found in Oesolcucumaria. Elements in the body wall in Oesolcucumaria are sparse and difficult to make out under SEM but appear to be very fine, simple, solid, acicular rods or crosses (Figure 1.2), like those found in many Palaeozoic sponges (e.g., Rigby and Gutschick, 1976; Rigby and Toomey, 1978; Schallreuter, 1991; Kozur et al., 1996; Maletz and Reich, 1997; Mehl and Lehnert, 1997; Botting, 2003, 2004; Botting and Muir, 2011). Rodlike and/or cruciform elements do occur in holothurians (Figure 2.2-10) but these are never simple acicular and show branched or perforated flattened or even spinose tips (Figure 2.1, 2.11-12).

A synapomorphy uniting all holothurians is the presence of a ring of large skeletal elements sur- 


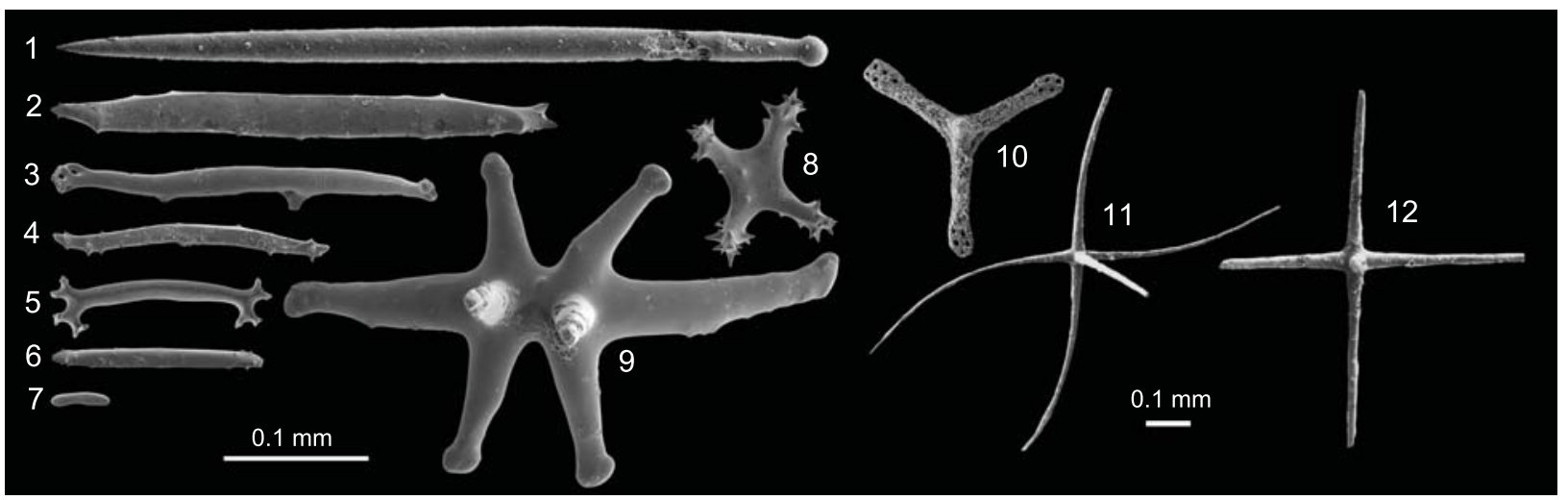

FIGURE 2. Comparison of rod- and cruciform-like sclerites of sponges (1, 11-12) and holothurians (2-10); 1, fossil isolated tylostyl (Demospongea), Eocene: Ypresian, Wobbanz, Isle of Rügen, Germany, GZG.001251/19 [from Ansorge and Reich, 2004]; 2, 4, 6, 8, Recent Laetmogone violacea Théel (Elasipodida: Laetmogonidae), North Atlantic Ocean, water depth 1,015 m, SMNH.110035/110036; 3, Recent Echinocucumis hispida (Barrett) (Dactylochirotida: Ypsilothuriidae), Norwegian Sea, water depth 100-300 m, SMNH.110122/110124; 5, Recent Trochodota purpurea (Lesson) (Apodida: Chiridotidae), southern Atlantic Ocean, water depth 11-13 m, SMNH.110131/110132; 7, Recent Chiridota pisanii Ludwig (Apodida: Chiridotidae), South Atlantic Ocean, water depth 10 m, SMNH.110126/110128; 9, Recent Elpidia heckeri Baranova (Elasipodida: Elpidiidae), Arctic Ocean, water depth 2,700 m, SMNH.110012/10013; 10, fossil cross-shaped table of Tribrachiodemas ordovicicus Reich (Aspidochirotida: Synallactidae), Late Ordovician (Katian/ Hirnantian), Sweden, GZG.INV.20072 [from Reich, 2010b]; 11-12, fossil isolated pentactines (Hexactinellida), early Silurian (Telychian), Sweden, GZG.INV.24436, 24706 [from Maletz and Reich, 1997]. Abbreviations: GZG, Geoscience Centre, Georg-August University of Göttingen, Germany; MHI, Muschelkalk-Museum Ingelfingen, Germany; ROM, Royal Ontario Museum, Toronto, Canada; SMNH, Swedish Museum of Natural History, Stockholm, Sweden.

rounding the pharynx (Figure 3 ). This calcareous ring acts as an anchor for the anterior section of the water vascular system including the buccal tentacles and also for the longitudinal and (if present) retractor muscles. The ring is composed of 10 cylindrical elements that abut and are arranged with pentaradial symmetry - five radial elements (R) alternating with five interradial elements (IR).
This structure is clearly and unambiguously seen in Palaeozoic holothurian body fossils, such as the Silurian Porosothyone (Jell, 2011), the Devonian Andenothyone (Haude, 1995b), Nudicorona (Haude, 1995a, 1997), and gen. et sp. nov. (Hunsrück Slate, Bartels et al., 1998). In the Carboniferous Mazon Creek Lagerstätte, an undescribed apodid holothurian preserves in addition the diges-

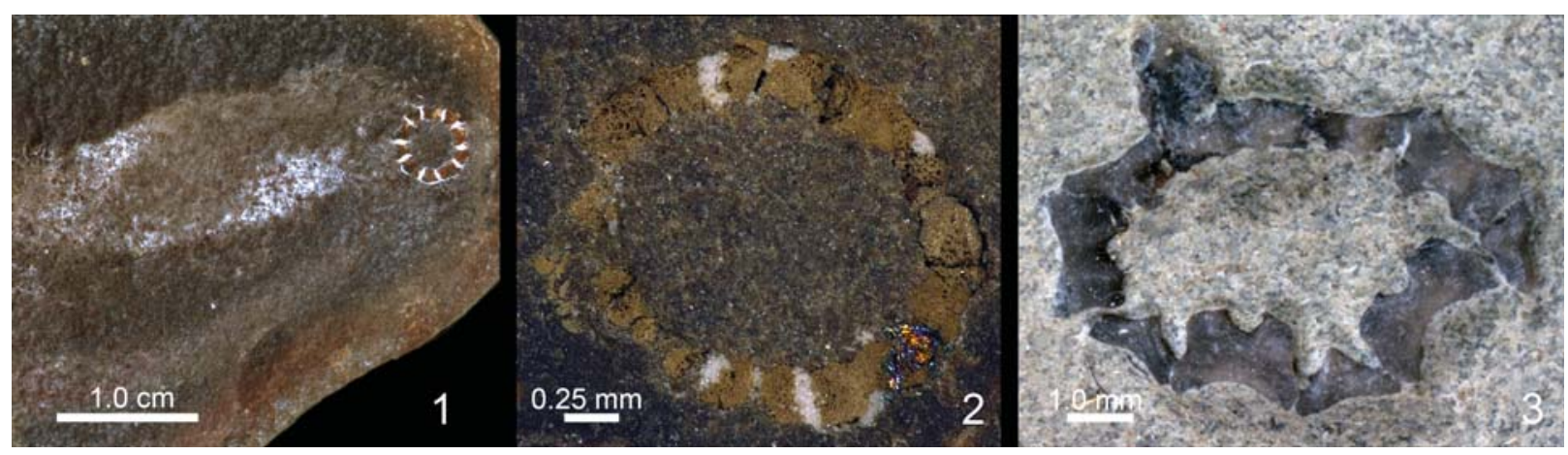

FIGURE 3. Holothurian body fossils, showing the preserved calcareous ring of 'standard architecture' with 5 radial and 5 interradial plates, and stereom structure of single elements. 1-2, Undescribed apodid holothurian body fossil with calcareous ring and body wall ossicles in situ, late Pennsylvanian Mazon Creek fossil Lagerstätte, Illinois, USA; 1, GZG.INV.50000 showing the calcareous ring and the body outline, 2, ROM.58481 showing the calcareous ring with stereom structure; 3, Undescribed aspidochirotid calcareous ring (Holothuriidae) with well-preserved radial and interradial elements, from a Triassic obrution deposit Lagerstätte in southern Germany, Upper Muschelkalk (Ladinian) MHI.1230 [from Reich, 2004, detail]. Abbreviations as in Figure 2. 
tive tract, which is encircled by the circumoral ring at its oral end (Reich and Stegemann, 2010; Figure 3.1). Elements of this ring structure have a distinctive, highly structured morphology and, when viewed under SEM, show always the characteristic stereom microstructure (Figure 4), and this is the case even for isolated ring elements from Ordovician and Silurian deposits (e.g., Reich, 1999; Figure 4.5-8). Oesolcucumaria, by contrast, has a large opening with a thickened lip (Figure 1.1, 1.35), similar to small hexactinellid sponges figured by Botting et al. (2011, fig. 2G-J). This structure consists of a random, irregular pattern of ridges and sediment-filled pits showing no pentaradial symmetry (Figure 1.4). High-resolution images of this region show a fine granular texture (Figure 1.5) and no trace of stereom could be found anywhere. The style of preservation in Oesolcucumaria contrasts with that seen in definitive echinoderms from this horizon where plates preserve traces of a stereom meshwork (see the illustration of the mitrate carpoid Anatifopsis? in Botting and Muir, 2012, fig. 5.1).

Botting and Muir (2012, p. 21) suggested Oesolcucumaria was related to modern Apodida, based on the presence of 'multiple internodals' (a term which is applicable in crinoids, but not in holothurians) in its multi-plated ring. Palaeozoic holothurians, however, accommodated additional tentacles by adding anterior processes to their 10 ring elements, not by adding additional plates. Modern holothurians in which the total number of calcareous ring elements has been increased to accommodate extra tentacles do occur, but only in advanced Synaptidae in Cenozoic times and always retain clearly differentiated radial and interradial elements.

Two additional points are worth noting. Despite preservation of the soft tissue body outline, there is no trace of a digestive tract preserved, and the presence of differentiation of 'ambulacral zones' reported in the original description simply cannot be confirmed. The latter assumption of the authors (Botting and Muir, 2012, p. 21-22) is mainly based on a misinterpretation of the stone canal of Palaeocucumaria (Devonian Hunsrück Slate, Germany) in X-radiographs by Haude (1994, 1995a, 2002) and others (Reich and Smith, pers. obs.).

Bold claims need strong evidence. Without evidence for stereom, pentaradial symmetry, diagnostic body wall spiculation or an organized calcareous ring there is no case for assigning
Oesolcucumaria to the class Holothuroidea or indeed to the phylum Echinodermata. The fine and delicate cruciform and bipolar acicular needles in the body and a single large circular opening with a strengthened rim seem more indicative of poriferan affinities, though stronger evidence is clearly needed to resolve its true taxonomic affinities.

\section{ACKNOWLEDGEMENTS}

$M R$ is grateful to Jean-Bernard Caron (ROM), Hans Hagdorn (MHI), David Rudkin (ROM), Sabine Stöhr (SMNH) and Janet Waddington (ROM), who provided assistance during visits and the loan of fossil and recent holothurian material. MR also acknowledges the financial support of the projects SE-TAF-799 and GB-TAF-2446 by SYNTHESYS (http://www.synthesys.info/), a programme that is financed by European Community Research Infrastructure Action, as well as (in part) by the German Research Foundation (RE 2599/4-1). SZ is funded by a Post Doctoral grant (EX2009-0815) and projects CGL2012-39471 and CGL2011-24516 from the Spanish Ministry of Economy and Competitiveness.

\section{REFERENCES}

Ansorge, J. and Reich, M. 2004. Die Eozän-Tonschollen von Wobbanz (SE-Rügen). Archiv für Geschiebekunde, 3(8/12):651-678.

Bartels, C., Briggs, D.E.G., and Brassel, G. 1998. The fossils of the Hunsrück Slate. Marine life in the Devonian. Cambridge Palaeobiology Series 3, 309 pp.

Botting, J.P. 2003. Growth patterns of Lower Palaeozoic sponges. Lethaia, 36:41-52.

Botting, J.P. 2004. An exceptional Caradoc sponge fauna from the Llanfawr Quarries, central Wales and phylogenetic implications. Journal of Systematic Palaeontology, 2:31-63.

Botting, J.P. and Muir, L.A. 2011. A new Middle Ordovician (late Dapingian) hexactinellid sponge from Cumbria, UK. Geological Journal, 46:501-506.

Botting, J.P. and Muir, L.A. 2012. Fauna and ecology of the holothurian bed, Llandrindod, Wales, UK (Darriwilian, Middle Ordovician), and the oldest articulated holothurian. Palaeontologia Electronica, 15.1:9A, 28 pp.

palaeo-electronica.org/content/2012-issue-1-articles/ 191-welsh-holothurian-bed

Botting, J.P., Muir, L.A., Sutton, M.D., and Barnie, T. 2011. Welsh gold: A new exceptionally preserved pyritized Ordovician biota. Geology, 39(9):879-882.

Gilliland, P.M. 1993. The skeletal morphology, systematics and evolutionary history of holothurians. Special Papers in Palaeontology, 47:1-147. 


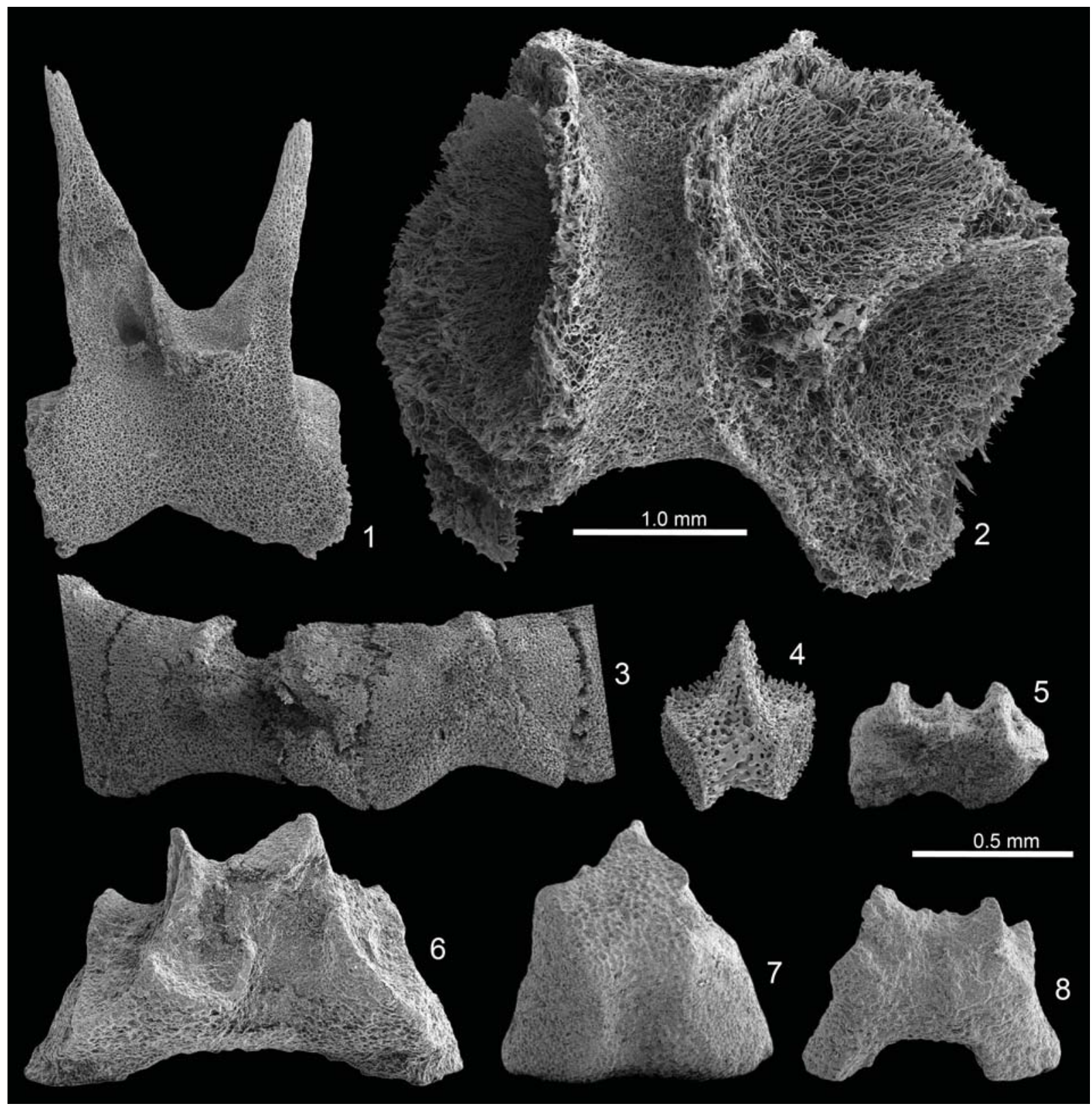

FIGURE 4. Morphology of modern and fossil holothurian calcareous ring elements showing the typical stereo architecture; 1, outer view of right dorsolateral radial element, Recent Myriotrochus rinkii Steenstrup (Apodida: Myriotrochidae), Arctic Ocean, water depth 22 m, SMNH.110016/110019; 2, inner oblique view of an radial element, Recent Laetmogone violacea Théel (Elasipodida: Laetmogonidae), North Atlantic Ocean, water depth 1,015 m, SMNH.110035/110037; 3, outer view of an radial (left) and interradial element (right), Recent Chiridota pisanii Ludwig (Apodida: Chiridotidae), South Atlantic Ocean, water depth 10 m, SMNH.110126/110128; 4, inner view of an interradial element Eupyrgus scaber Lütken (Molpadiida: Eupyrgidae), North Atlantic Ocean, water depth 30-80 m, SMNH.110029/110031; 5, undescribed fossil radial element (stem group Apodida), inner view, middle Ordovician (early Darriwilian), Germany/Sweden, GZG.INV.20001; 6, undescribed fossil radial element (Apodida), outer view, late Silurian (Ludfordian), Gotland, Sweden, GZG.INV.13251; 7, undescribed fossil interradial element (stem group Apodida), inner view, late Silurian (Ludfordian), Gotland, Sweden, GZG.INV.40710; 8, undescribed fossil radial element (Aspidochirotida), inner view, late Silurian (Ludfordian), Gotland, Sweden, GZG.INV.13255. Scale: $1.0 \mathrm{~mm}$ (12); $0.5 \mathrm{~mm}$ (3-8). Abbreviations as in Figure 2. 
Haude, R. 1994. Fossil holothurians: Constructional morphology of the sea cucumber, and the origin of the calcareous ring, p. 517-522. In David, B., Guille, A., Féral, J.-P., and Roux, M. (eds.) Echinoderms through Time. Proceedings of the 8th International Echinoderm Conference, Dijon, France, 6-10 September 1993. Balkema, Rotterdam/Brookfield.

Haude, R. 1995a. Die Holothurien-Konstruktion: Evolutionsmodell und ältester Fossilbericht. Neues Jahrbuch für Geologie und Paläontologie, Abhandlungen, 197:181-198.

Haude, R. 1995b. Echinodermen aus dem Unter-Devon der argentinischen Präkordillere. Neues Jahrbuch für Geologie und Paläontologie, Abhandlungen, 197:3786.

Haude, R. 1997. Nudicorona, eine devonische Holothurie. Fossilien, 14:50-57.

Haude, R. 2002. Origin of the holothurians (Echinodermata) derived by constructional morphology, p. 141153. In Aberhan, M., Heinrich, W.-D., and Schultka, S. (eds.) Festband: Hans-Peter Schultze zum 65. Geburtstag. Mitteilungen aus dem Museum für Naturkunde in Berlin, Geowissenschaftliche Reihe, 5.

Jell, P.A. 2011. Late Silurian Echinoderms from the Yass Basin, New South Wales - the earliest holothurian body fossil and two diploporitan cystoids (Sphaeronitidae and Holocystitidae). Memoirs of the Association of Australian Palaeontologists, 39:27-41.

Kozur, H.W., Mostler, H., and Repetski, J.E. 1996. 'Modern' siliceous sponges from the lowermost Ordovician (Early Ibexian - Early Tremadocian) Windfall Formation of the Antelope Range, Eureka County, Nevada, U.S.A. Geologisch-Paläontologische Mitteilungen Innsbruck, 21:201-221.

Maletz, J. and Reich, M. 1997. Radiolarians and sponge spicules from the Spirograptus turriculatus Zone (Llandovery, Silurian) of the Siljan district, Dalarna (Sweden). Greifswalder Geowissenschaftliche Beiträge, 4:101-111.

Mehl, D. and Lehnert, O. 1997. Cambro-Ordovician sponge spicule assemblages in the Ordovician of the Argentine Precordillera and paleoenvironmental ties. Neues Jahrbuch für Geologie und Paläontologie, Abhandlungen, 204:221-246.

Reich, M. 1999. Ordovizische und silurische Holothurien (Echinodermata), p. 479-488. In Reich, M. (ed.) Festschrift zum 65. Geburtstag von Ekkehard Herrig. Greifswalder Geowissenschaftliche Beiträge, 6.

Reich, M. 2001. Ordovician holothurians from the Baltic Sea area, p. 93-96. In Barker, M. (ed.) Echinoderms 2000: Proceedings of the 10th International Conference, Dunedin, 31 January - 4 February 2000. Balkema Publishers, Lisse etc.
Reich, M. 2004. Aspidochirote holothurians (Echinodermata) from the Middle Triassic of southern Germany, p. 485-486. In Heinzeller, T., and Nebelsick, J.H. (eds.) Echinoderms: München. Proceedings of the 11th International Echinoderm Conference, Munich, Germany, 6-10 October 2003. Balkema Publishers, Leiden etc.

Reich, M. 2010a. The early evolution and diversification of holothurians (Echinozoa), p. 55-59. In Harris, L.G., Böttger, S.A., Walker, C.W., and Lesser, M.P. (eds.) Echinoderms: Durham. Proceedings of the 12th International Echinoderm Conference, Durham, New Hampshire, USA, 7-11 August 2006. Taylor \& Francis, London etc.

Reich, M. 2010b. The oldest synallactid sea cucumber (Echinodermata: Holothuroidea: Aspidochirotida). Paläontologische Zeitschrift, 84:541-546.

Reich, M. in press. How many species of fossil holothurians are there ? In Johnson, C. (ed.) Echinoderms in a Changing World. Proceedings of the 13th International Echinoderm Conference, January 5-9 2009, University of Tasmania, Hobart Tasmania, Australia. Taylor \& Francis Group, London etc.

Reich, M. and Stegemann, T. 2010. Holothurians (Apodida) from the Late Palaeozoic Mazon Creek Fossillagerstätte (Illinois, USA), p. 90-91. In Reich, M., Reitner, J., Roden, V., and Thuy, B. (eds.) Echinoderm Research 2010. 7th European Conference on Echinoderms, Göttingen, October 2-9, 2010. Abstract Volume and Field Guide to Excursions. Universitätsverlag, Göttingen.

Rigby, J.K. and Gutschick, R.C. 1976. Two new Lower Paleozoic hexactinellid sponges from Utah and Oklahoma. Journal of Paleontology, 50:79-85.

Rigby, J.K. and Toomey, D.F. 1978. A distinctive sponge spicule assemblage from organic buildups in the Lower Ordovician of southern Oklahoma. Journal of Paleontology, 52:501-506.

Schallreuter, R. 1991. Mikrofossilien aus dem Ostrakodenkalk (Silur) der Lindener Mark bei Gießen (Hessen). Neues Jahrbuch für Geologie und Paläontologie, Monatshefte, 1991(2):105-118.

Seilacher, A. 1981. Funktionelle Abwandlung des Echinodermen-Stereoms, p. 49-60. In Reif, W.-E. (ed.) Paläontologische Kursbücher, 1: Funktionsmorphologie. Paläontologische Gesellschaft, München.

Smith, A.B. and Gallemí, J. 1991. Middle Triassic holothurians from northern Spain. Palaeontology, 34:4976. 